\title{
A European Solution for a European Crisis. The International implications of Portugal's Revolution
}

\author{
Mario DEL PERO
}

This article deals with the European dimension of the Portuguese crisis of 1974-75. The outcome of the crisis was impossible to predict and the risks of either an extreme radicalization of the post-revolutionary transition or of a neo-authoritarian reaction to it could not be discounted. The United States and its main European allies reacted differently to the Portuguese revolution of April 1974 and to what ensued. The latter dreaded a possible replica of the Chilean coup in Portugal and actively worked to prevent it; Washington instead feared a shift to the Left that could induce Portugal to abandon the Atlantic alliance and move closer to the Soviet bloc, and did not rule out the possibility of supporting an authoritarian response. Many Western European countries, and the socialist parties and governments overall, viewed the Portuguese crisis as a crucial text of Europe's ability to offer an inclusive model of democracy and modernization. The main argument of the article is that such model was very popular in the least developed areas of Europe, as the electorate of Portugal made abundantly clear, and could offer a stabilizing alternative to the now discredited logics and partitions of the Cold War.

The article is divided into three parts. In the first I examine Portugal's peculiar position in the early Seventies and the dilemmas the United States and Western Europe faced in dealing with the Portuguese regime. In the second I discuss the international impact of the Portuguese revolution and the different responses to it given by the United States and its European allies. The third and last part is dedicated to how domestic and international factors interacted in determining the outcome of the crisis.

\section{Portugal and Détente}

In the early 1970s the United States and some of its most important European allies diverged radically on how to deal with the authoritarian Portuguese regime. For the Europeans, a rapid economic integration of Portugal represented the essential precondition for facilitating its gradual transition to a more liberal and possibly democratic system. The previous decade had been characterized by significant changes in Portugal's economy and trade patterns. The importance of the African colonies for Portuguese trade had considerably diminished; Europe had become the main commercial partner of Lisbon; participation in the European Free Trade Association (EFTA) had had a relevant impact on Portugal's economy, which grew at accelerated rate (ca. $6 \%$ per year) and became more efficient and productive. In 
the same years, emigration to Europe increased dramatically, as did foreign investments in Portugal. The trade agreement signed with the EEC in June 1972 represented a watershed and stimulated a further rise in the commercial exchanges between Portugal and the EEC countries: in the early 1970s, almost fifty percent of Portuguese imports and exports were with members of the European Community. The agreement accelerated the inclusion of Portugal and its economy in Europe. Such gradual inclusion revealed the irreconcilable antagonism between the preservation of the African colonies and any further, and much needed, 'Europeanization' of Portugal. "From that moment on", political scientist Nuno Severiano Teixeira has convincingly argued,

"it became evident that Portugal's accession to the EEC was not only dependent upon the existence of certain economic conditions, but also on the need for democratization and decolonization". ${ }^{1}$

This economic integration and partial 'Europeanization' of Portugal combined with the propensity of many Western European countries to adopt a more critical posture towards the Portuguese authoritarian regime. During the 1960s, some European countries - Norway and Sweden in particular - had bitterly censured Portugal's colonialism and the lack of political freedom in Portugal. Atlantic allegiance, Cold War logics and geopolitical considerations had however concurred to contain these voices and prevent an absolute isolation of Portugal. ${ }^{2}$

In the late Sixties/early Seventies, Portugal became nonetheless more isolated and its presence - within Atlantic and European institutions - was considered a source of embarrassment by many Western European governments. Socialist and Social Democratic parties stepped up their efforts to support democratic forces in Portugal. Denunciations of Portuguese colonialism grew louder, particularly at the United Nations. Some countries, Sweden again, provided greater economic and

1. N. SEVERIANO TEIXEIRA, From Africa to Europe. Portugal and European Integration, in: A. COSTA PINTO, N. SEVERIANO TEIXEIRA (eds.), Southern Europe and the Making of the European Union, Columbia University Press, New York, 2002, p.24; D. CORKILL, Portugal's Changing Integration into the European and Global Economy, in: S.SYRETT (ed.), Contemporary Portugal. Dimensions of Economic and Political Change, Ashgate, Burlington, 2002, pp.83-103; L. AMARAL, How a Country Catches Up: Economic Growth in Portugal in the Post-War Period (1950s-1973), PhD dissertation, European University Institute, Florence, 2002.

2. L.N. RODRIGUES, Salazar-Kennedy: a crise de uma aliança. Relações luso-americanas entre 1961 e 1963, Notícias Editorial, Lisboa, 2002; Id., About Face: the United States and Portuguese Colonialism in 1961, in: E-Journal of Portuguese History, 2(2004) (http://www.brown.edu/ Departments/Portuguese_Brazilian_Studies/ejph/html/issue3/pdf/lnrodrigues.pdf). 
material support to anti-colonial groups operating in the African colonies of Portugal. $^{3}$

Portugal's position vis-à-vis the rest of Western Europe was a paradoxical mix, which combined the desire (and necessity) to become part of it and the growing consciousness that only drastic political changes would permit to achieve this goal. While differing significantly among themselves, Western European countries knew that tolerating the Portuguese regime was politically unpopular and that gestures of explicit ostracism were often necessary. They also knew that a democratic evolution of Portugal would be a crucial test for Western Europe and for its alleged capacity to offer a specific model, of modernization and democracy.

The United States adopted instead a different approach. After 8 years of tensions and occasional clashes with Portugal, the Nixon administration abandoned the stances of the Kennedy and Johnson administrations, which had oscillated between confrontation and neglect. Richard Nixon promoted an intense effort aimed at improving the relationship with the Portuguese regime. He called the previous US attitude towards Portugal "unjust". National Security adviser Henry Kissinger would later describe António Salazar's and Marcelo José Caetano's Portugal as an inefficient, but benign regime, the United States could do business with. ${ }^{4}$

There were several motivations behind the efforts of Nixon and Kissinger to promote a new engagement with Portugal. The new Republican administration was generally less concerned with (and disturbed by) violent repression of political dissidents, in Portugal and the colonies. Furthermore, while auspicating a gradual loosening of Portugal's control over its African colonies and some degree of autonomy for them, Nixon and Kissinger looked with scepticism at the possibility of a rapid decolonization, and were hostile to some of the most important independentist groups, including those, such as Holden Roberto's FRELIMO, which the US had supported in the past. Fears that the Soviets might exploit the wars in Africa to increase their presence and influence in the region added a further rationale for improving the relationship with Lisbon. Caetano's appeals to the "civilizing mission" of the West in Africa and his virulent anti-Communism did

3. On the hostility of the Scandinavian Social Democrats toward the Portuguese regime and its participation in NATO, see the considerations in Nixon Presidential Materials (hereinafter NPM), National Archives and Records Administration, College Park, Maryland (hereinafter NARA), National Security Council Files - Country Files: Europe (hereinafter NSC-CFE), Box 701, Rogers to Nixon, 06.04.1971. See also the monumental research of T. SELLSTRÖM, Sweden and National Liberation in Southern Africa, vol.II: Solidarity and Assistance, 1970-1994, Nordiska Afrikainstituet, Uppsala, 2002; P.A. OLIVEIRA, A Politica Externa, in: F. ROSAS, P.A. OLIVEIRA (eds.), A Transição Falhada. O Marcelismo e o Fim do Estado Novo (1968-1974), Editorial Notícias, Lisboa, 2004, pp.303-337.

4. Gerald R. Ford Library, Ann Arbor Michigan (hereinafter GRFL), National Security Adviser (hereinafter NSA), Memoranda of Conversations, 1973-77 (hereinafter MOC), Memorandum of Conversation Kissinger/Ford/Reza Pahlavi, 15.05.1975; W.W. SCHNEIDMAN, Engaging Africa: Washington and the Fall of Portugal's Colonial Empire, University Press of America, Lanham, 2004, p.112. 
not arouse much sympathy in Washington. His frequent references to the worldwide geopolitical struggle with the Soviet Union and the consequent necessity of widening the area covered by the Atlantic alliance and the scope of NATO's mission did instead strike a chord in the US. Kissinger, in particular, shared the conviction that Portugal's territories in Africa constituted NATO's southern frontier, to the extent of defining Portugal "a NATO ally defending the West on its African flank". 5

This strategic rationale was compounded by the importance of the US military base in the Azores at Lajes. Kissinger and several members of the administration emphasized the value of Lajes with regard to the more general geopolitical concerns of the United States in Southern Europe. Domestic political turmoil and instability, the loosening of Cold War discipline - particularly in Italy - Middle East tensions and Soviet activism in the Mediterranean rendered Southern Europe more central and important for Washington. This renewed centrality was stressed in the 1970 National Security Study Memoranda dedicated to the area. According to Kissinger's advisers — Robert Osgood, Harold Saunders, and Helmut Sonnenfeldt - 'the USSR ha[d] broken out of 'containment' and the Mediterranean itself ha[d] become the arena of contest [...] and not 'the route to somewhere important' anymore". Lajes had always been a crucial variable in the overall equation defining US attitudes towards Portugal, as well as the main diplomatic asset at Lisbon's disposal in its relationship with the United States. All the more so at this specific historical juncture, considering that the old treaty had expired and the US military was using the military installation on a de facto basis. ${ }^{6}$

Finally, Portugal seemed to represent a reliable ally for Washington in a period characterized by a reduction of Atlantic and Cold War discipline and by the attempt of many lesser allies of the United States to promote a partially independent foreign policy. For Kissinger and Nixon détente served also to contain and reverse various centrifugal processes then developing within the Western bloc. Differently from other European partners of the US, Portugal fit perfectly in

5. NPM, NARA, NSC-CFE, Box 701, Memorandum of conversation Nixon-Caetano-Kissinger, 01.04.1969. On Caetano's emphasis on the civilization struggle of the West in Africa see also NPM, NARA, NSC-CFE, Box 701, Memorandum of conversation Caetano-Rogers-Patricio (Portugal's Foreign minister), 30.05.1970; Memorandum of Conversation Kissinger/Ford/Reza Pahlavi, 15.05.1975, GRFL, NSA, Memoranda of Conversations, 1973-77 (hereinafter MOC); Kissinger quoted in W.W. SCHNEIDMAN, op.cit., p.120. On the Cold War and the Portuguese colonies, see also N. Mac QUEEN, The decolonization of Portuguese Africa: metropolitan revolution and the dissolution of empire, Longman, London, 1997.

6. NPM, NARA, National Security Council Files - President's Trip Files (hereinafter NSC-PTF), Box 351,f. 'Mediterranean Policy', Meeting on the NSSM on the Mediterreanean and United States security (participants: Robert E. Osgood, Harold Saunders and Helmut Sonneneldt), 26-27.02.1970; L.N. RODRIGUES, As negociações que nunca acabaram: a renovação do acordo das Lajes em 1962, in: Penelope, 22(2000), pp.53-70; Á. de VASCONCELOS, A Dupla Ilusão, in: J.C. de MAgalhãeS, Á. de VASCONCELOS, J.R. SILVA (eds.) Portugal. Paradoxo Atlântico. Diagnóstico das relações Luso-Americanas, Fim De Século, Lisbona, 1993, pp.59-98; M. CESA, Defining Security: the Case of Southern Europe and the Superpowers in the Mediterranean, ETS, Pisa, 1989. 
Kissinger's vision of a unified, monolithic, and US-led Western bloc. Unlike other Western European countries, there was no risk that Portugal could undertake an autonomous rapprochement with the Soviet Union and the Eastern Bloc. Furthermore, its Atlantic allegiance did not seem threatened by domestic political turmoil and the potential advent of anti-Atlantic, neutralist, or even (Euro)communist forces. ${ }^{7}$

This renewed dialogue and cooperation between the United States and Portugal produced several results. In 1971 the two countries finally agreed on a renewal of the lease of the US base in the Azores. Washington modified its approach in regard to the wars in Portugal's colonies, actively supported Lisbon at the United Nations and weakened the embargo on the sale of arms as well as the controls on the private transfer to Portugal of non military items that could be used in its African wars. As emphasized by Witney Schneidman in a recent work, "by the end of the first Nixon administration, American ties with Portugal were stronger than at any time since the Eisenhower administration". ${ }^{8}$

There were, however, clear limits on what the American and Western European governments could do, and their approach to Portuguese matters were often erratic and incoherent. While the latter could not act as a unitary actor and often preferred a cautious step-by-step approach, the former had to face domestic opponents who were harshly critical of the new Portuguese policy of the Nixon administration. Liberal members of Congress and the recently formed Black Congressional Caucus challenged Nixon and Kissinger. In 1973 the Senate succeeded in passing laws that made permanent the embargo on the transfer of arms that Portugal could use in Africa and attached clauses that rendered more difficult for the administration to fulfil its obligations under the terms of the 1971 agreement over Lajes. The mainstream media provided additional ammunition to Portugal's critics in the US. In late 1973 the "New York Times" argued that Portugal was destined to "remain something of an embarrassment to its allies so long as it practice[d] repression at home and outdated colonialism in Africa". 9

7. I have argued this in M. DEL PERO, I limiti della distensione. Gli Stati Uniti e l'implosione del regime portoghese, in: Contemporanea, 4(October 2005), pp.621-650; Idem., The Eccentric Realist. Henry Kissinger and the Shaping of American Foreign Policy, Cornell University Press, Ithaca, NY, Cornell, 2009.

8. W.W. SCHNEIDMAN, op.cit., p.128; M. DEL PERO, I Limiti ..., op.cit.; P.A. OLIVEIRA, op.cit.

9. Charade in Portugal, in: The New York Times, 27.10.1973; M. DEL PERO, The Limits of Détente. The United States and the Crisis of the Portuguese Regime, in: W. LOTH, G.-H. SOUTOU (eds.), The Making of Détente. Eastern and Western Europe in the Cold War, 1965-1975, Routledge, London, 2008, pp.221-240. 


\section{Misperceptions and misunderstandings}

The new war in the Middle East of October 1973 represented a crucial turning point also for Portugal. The attack of Syria and Egypt came unexpected and Israel found itself in grave danger. For diplomatic and political reasons, Kissinger initially decided to delay the re-supply of the Israeli ally. The US, however, had to rely on an unwilling Portugal in order to carry out the airlift. Without the use of the Lajes base, which Lisbon grudgingly granted, the military re-supply of Israel would have been much more difficult and the course of the war probably different. ${ }^{10}$

For Kissinger and Nixon the episode proved, once again, Portugal's trustworthiness. Portugal's loyalty was compared to the behaviour of the other European allies. "The Europeans behaved like jackals", Kissinger said during a discussion with his staff. "Whatever we may think of its African policy", he continued,

"Portugal has been the only European ally that has made this policy possible [...]. I mean if we are going to be tough on those who don't cooperate, we have to be helpful to those who do [...]. I do want the Portuguese to be rewarded for having been the only European country to help us in the Middle East". ${ }^{11}$

In the following months, Kissinger (who had also been appointed secretary of State) and his staff discussed various schemes for rewarding Portugal, which was suffering from OPEC's oil embargo as a consequence of its role in the war. These discussions took place without noticing Portugal's grave crisis nor foreseeing the ineluctable implosion of the Portuguese regime and its crumbling empire. Despite warnings of domestic political unrest, growing tensions within the army, and the publication in March 1974 of general Antonío de Spinola's book, Portugal e o futuro, which called for a change of policy in Africa, the United States was completely unprepared for the dramatic events of April 1974. European observers, however, were also surprised by the sudden collapse of the regime, whose consequences they were ill-equipped to face. Even after the publication of Spínola's book, most of them believed that the crucial struggle in Portugal was between the liberal and conservative wings of the armed forces, and completely

10. J.F. ANTUNES, Portugal na Guerra do Petróleo. Os Açores e as Vitórias de Israel 1973, Edeline, Lisboa, 2000. See also W. QUANDT, Peace Process: American Policy Toward the ArabIsraeli Conflict, University of California Press, Berkely, 1984, pp.162-163. The most important documents in the US archives are: NPM, NARA, NSC-CFE, Box 701, Post (US embassy in Lisbon) to Kissinger, "Lajes Flights", 12.10.1973; Kissinger to US embassy in Lisbon, 12.10.1973; NARA, NPM, Henry Kissinger Telephone Conversations Transcripts (hereinafter HKTCT), Chronological File (hereinafter CF), Box 23 (October 12, 1973 to November 19, 1973), conversation Kissinger-Schlesinger (secretary of Defense). The harsh message sent by Nixon to Caetano, in which the US president asked for the use of Lajes base, can be found in NPM, NARA, NSC-CFE, Box 701, Kissinger to US embassy in Lisbon, "Lajes Flights", 13.10.1973; the clash between the two governments is also discussed during a telephone conversation between Kissinger and Schlesinger on the afternoon of the same day, NARA, NPM, HKTCT, CF, Box 23.

11. NARA, RG 59, Lot File 78D443, Box 1, Meeting of secretary of State's Staff, 18.10, 23.10 and 26.11.1973. 
underestimated the importance of the radical young officers who will promote and lead the revolutionary process. While discussing the political implications of the publication of Portugal e o futuro, John Ure, the British chargé d'affaires in Lisbon, foresaw the possibility of "a further period of national debate in which the ideas he has propounded might slowly achieve more general support". "The worse that could happen", Ure maintained "is that the Right wing may feel that they have demonstrated who is the master". ${ }^{12}$

Despite their common surprise and unpreparedness, the US and its European allies reacted however differently to the events in Lisbon. This difference would only intensify in the ensuing months, adding a further divisive factor in what was already a very strained Transatlantic relationship. The Nixon administration, and Kissinger in particular, distrusted the new government, which comprised all the antiSalazarist parties including the Communists, and were sceptical about its ability to grant the colonies a gradual autonomy within a Portuguese-speaking federation, as hoped by the new president, general Spínola. Furthermore, the president and his secretary of State had little clue of what was happening in Portugal and tended to read events through a very ideological Cold War prism. "My prediction" Kissinger said -

"has always been there are only two ways it can go. Either the military will take over, or the left wing will take over $[\ldots]$ it will begin to polarize between the extreme Left and the military. Then the military will move against the extreme Left, or the extreme Left will pre-empt it". ${ }^{13}$

Western European leaders, instead, greeted with enthusiasm the revolution, foresaw the possibility of a rapid transition to a democratic system and found inevitable, and not particularly troublesome, the inclusion in the government of the pro-Soviet Portuguese Communist Party (Partido Comunista Português, PCP). In early May, the new Portuguese Foreign minister, the Socialist Mario Soares, met with three socialist members of the ECC (Altiero Spinelli, Henri Simonet, and George Thompson) and discussed the possibility of greater collaboration. A few days later, EFTA's members expressed their support for Portugal's transition to democracy and their willingness to provide economic aid. Western European leftist

12. National Archives of the United Kingdom, Kew Garden, London (hereinafter NAUK), Foreign \& Commonwealth Office (hereinafter FCO) 9/2046, Ure to Foreign and Commonwealth Office (hereinafter FCO), 26.03.1974; K. MAXWELL, The Making of the Portuguese Democracy, Cambridge University Press, Cambridge/New York, 1995, pp.65-67. On the importance of the book by A. de SPÍNOLA, Portugal e o futuro: análise da conjuntura nacional, Arcadia, Lisboa, 1974), see M.I. REZOLA, As forças armadas, os capitães e a crises final do regime, in: F. ROSAS, P.A. OLIVEIRA (eds.), A Transição Falhada ..., op.cit., pp.339-372; M. ANTUNES, $O$ Sonhador Pragmático. Entrevista de Maria Manuela Cruzeiro, Notícias Editorial, Lisboa, 2004, pp.83-86.

13. NARA, RG 59, Lot File 78D443, Box 4, Meetings of secretary of State's Staff, 26.04 and 10.07.1974. 
parties and trade unions channelled funds and people to support their Portuguese counterparts and provide the necessary 'democratic know-how'. ${ }^{14}$

There was a certain degree of benevolent paternalism in the attitude of many Western Europeans, well on display in the considerations of British ambassador to Lisbon, Nigel Trench who, commenting on the first difficulties of the postrevolutionary government explained them by claiming that "the Portuguese" were "by and large a docile people, not unduly addicted to intellectual activity"; "a paternalistic regime, such as that of Salazar in his early years", Trench maintained, was "not by its nature unwelcome to many of them". Democracy, the ambassador argued, was therefore "compounded by the customs of the country and the national character". 15

It was, however, in the name of democracy and rapid decolonization that many Western European countries and the EEC embraced the Portuguese revolution. Mario Soares and the Socialist Party (Partido Socialista, PS) were conscious of this and played immediately the role of the most pro-European force in the country, promising rapid decolonization, urging economic help and asserting the necessity for Portugal to accelerate its integration in Europe and to embrace a model of modernization and economic development resembling the one dominant in Europe at the time. European socialists provided support and international legitimacy for the new Foreign minister. Writing to Kissinger, British Foreign minister James Callaghan declared to "have known Mario Soares for many years" and to "have considerable confidence in him". It was therefore necessary to offer "the Portuguese socialist party organizational and technical help in the belief that a government with their participation" was the one which offered "the best prospects for the West". To strengthen his image as the perfect interlocutor of the West and the only man capable of preserving stability in the country, Soares did not hesitate to arouse Cold War concerns, declaring the PS "the only force in the country capable of resisting the Communists" who had "the full backing of the Soviet Union" and likening the government of Portugal to "the immediate post-war governments in Italy and France". Soares would stick to this script for most of the post-revolutionary crisis, simultaneously presenting himself and his party as the most reliable bulwarks against communism, the best hope for a rapid 'Europeanization' of Portugal, and, also, as the only political force capable of preventing any possible, Chile-like, neo-authoritarian reaction. ${ }^{16}$

14. Portuguese Socialist Seeks Aid From Common Market Leaders, in: New York Times, 04.05.1974; M. ACOCA, Close Lisbon Ties to West Seen, in: Washington Post, 08.05.1974; Portugal is Backed by Trading Group, in: New York Times, 10.05.1974. EFTA would later create a Portugal Fund to support the modernization and democratization of the country.

15. NAUK, FCO, folder: 'FCO 9/2046', Trench to Wiggin, 05.06.1974.

16. NAUK, FCO, folder: 'FCO 9/2045', Callaghan to UK embassy in Washington, 03.05.1974; folder: 'FCO 9/2046', Report of Meeting between Soares and Canadian secretary of State for External Affairs, 17.06.1974; NARA, RG 59, Lot File 78D443, Box 3, Meeting of secretary of State's staff, 10.06.1974; Record of conversation between Harold Wilson and Mario Soares, 02.05.1974 in: Documents on British Policy Overseas (hereinafter DBPO), series III, vol.V: The Southern Flank in Crisis, 1973-1976, Routledge, London, 2006, pp.357-360. 
Kissinger was not impressed. He mistrusted Soares and considered him weak, naïve and indecisive: a "Portuguese Kerensky" in a brutal and typically Kissingeresque definition, which soon became public. The US secretary of State feared that hasty decolonization would advantage radical groups, such as the MPLA in Angola, and facilitate further Soviet penetration in Africa. More important, Kissinger viewed Portuguese events in light of broader geopolitical considerations. The presence of Communist ministers in the government of a NATO ally established a dangerous precedent, that could be replicated elsewhere, particularly in Italy, where the possibility of a historical compromise between Communists and Christian Democrats was discussed at the time. Symbolic considerations played a paramount role. What happened in Portugal could signal to the rest of Europe that despite its words America now tolerated a loosening of Atlantic discipline and a new season of 'popular frontism'. "When you imagine what communist Governments will do inside NATO", Kissinger would later ponder,

\begin{abstract}
“it doesn't make any difference whether they're controlled by Moscow or not. It will unravel NATO and the European community into a neutralist instrument. And that is the essence of it. Whether or not these parties are controlled from Moscow - that's a subsidiary issue $[\ldots]$ we keep saying that there's no conclusive evidence that they are not under the control of Moscow, implying that if we could show they were not under the control of Moscow, we could find them acceptable [...]. A Western Europe with the participation of communist parties is going to change the basis of NATO [...] to bring the communist into power in Western Europe [...] would totally reorient the map of postwar Europe". ${ }^{17}$
\end{abstract}

This sort of considerations and fears informed US behaviour throughout the postrevolutionary period. Initially, the US backed Spinola without hesitation, hoping he could be the Portuguese De Gaulle, capable of controlling radical forces at home and effectively managing decolonization in Africa. Nixon met the Portuguese president and vaguely promised economic aid and political support. The situation, however, deteriorated during the Summer of 1974. The collaboration between Spínola and the heterogeneous group of radical junior officers that had promoted the revolution and formed the so-called "Armed Forces Movement" (Movimento das Forças Armadas, MFA) proved impossible. A first set-back for the general was represented by the governmental crisis of July 1974, which led to the formation of a new government and the appointment of colonel Vasco Gonçalves as Prime minister. Gonçalves was much more sympathetic to the radical left, the PCP remained in the government and Mario Soares continued to be Foreign minister. It was the first of a series of shifts to the Left that troubled the US and its European allies alike.

The reactions were however different. From Lisbon Trench urged not to cry wolf and re-affirmed his trust in Soares and the Socialists: "in a country where, until two months ago, anyone who held views to the left of the British conservative

17. NARA, RG59, Lot File 78D443, Box 6 and Box 10, Meeting secretary of State's Staff, 12.01.1975 and 01.07.1976. 
party was liable to be denounced as a Communist", the British ambassador claimed, it was very complicated "to ascertain what a man's real political affiliations" were. The US adopted instead a more rigid stance. Kissinger and his advisers had scant faith in the capacity of Soares to prevent the Communists from dominating the government and the armed forces. Washington urged the NATO's secretary general to stop the distribution of top secret documents to the Portuguese representative and to suspend Portugal's participation in NATO's Nuclear Planning Group. The British representative was against this decision and deemed it as an "unnecessary humiliation" of Portugal, which "openly treat[ed] the Portuguese as untrustworthy second-class citizens" and "strengthen[ed] the anti-NATO sentiment in the Portuguese government and Armed Forces Movement". Denmark and the Netherlands concurred, and criticized the lack of consultation on such critical decision. They were however unable to convince the American government. The participation of Portugal in the activities of the NPG was thus suspended in October 1974. ${ }^{18}$

The tensions between the United States and its allies over Portugal increased in the Fall, after Spínola's downfall and another radicalization of the postrevolutionary process. In late September, Spínola called for a demonstration of the alleged "silent" (and conservative) majority to prove his political strength vis-à-vis the MFA and the parties. This decision backfired: the reaction of the latter led to the cancellation of the event. Spìnola resigned and was replaced by general Costa Gomes, who was much closer to the MFA leadership. The power of the MFA increased. The country appeared to be moving decidedly to the Left. ${ }^{19}$

For Kissinger it was the demonstration that without immediate action Portugal could soon be lost for the West. He criticized the moderation of both the positions of Washington's allies and the estimates of the US embassy in Lisbon, which seemed not to understand that the country was "moving inexorably in a leftist direction". His pessimism was shared however only by the Italian ambassador to Lisbon who, during a meeting of the EEC heads of mission in Portugal, proclaimed that "recent events were evidence of a Soviet plot to install a communist government". Fearing the possibility of a "popular front regime", European socialdemocrats stepped up their efforts in Portugal. European "reverend statesmen", such as Olof Palme and Willy Brandt, visited Portugal, as did Edmund P. Wellenstein, the director-general of External relations of the EEC, who met the Portuguese minister for Economy, Emílio Rui da Veiga Peixoto Vilar. Such visits, Ure argued, were also meant to "quieten those who were prophesizing the instant collapse of democratic practices". A crucial role was played by Costa Gomes

18. NAUK, FCO, 'FCO 9/2046', Trench to Wiggin, 17.07.1974. NPM, NARA, NSC-CFE, Box 701, Scott to Kissinger, 16.07.1974; NARA, Lot file 77D112 (Policy Planning Staff, Policy Planning Group, Director's Files) (Winston Lord), 1969-1977, Box 349, Briefing Paper on Portugal, 12.08.1974; NAUK, FCO 9/2066, Beaumont to Tickell, 07.08.1974; Peck to MacLaren, 05.09.1974; Thomas to Tickell, 24.10.1974. K. MAXWELL, The Making ..., op.cit., p.91; Portugal Arranges 5-year, \$ 150 Million Standby Credit, in: The Wall Street Journal, 20.08.1974.

19. M. ANTUNES, op.cit., pp.24-126; K. MAXWELL, The Making ..., op.cit., pp.102-103. 
himself, who was able to placate these fears by re-pledging Portugal's loyalty to NATO and gently accepting Portugal's exclusion from the NPG. ${ }^{20}$

Conscious of the risk of greater external interference and aware there was no way to contest Europe's Cold War division, all the major Portuguese political parties confirmed the Atlantic allegiance of the country and the impossibility to abandon unilaterally the Atlantic alliance. The PCP's leader himself, Alvaro Cunhal, reaffirmed this on several occasions and, in an interview with "The Wall Street Journal", maintained that while Portuguese Communists were "not in favour of such a military alliance, still [...] this [wasn't] the time to consider the question" which should instead "be settled within the larger framework of European security". ${ }^{21}$

\section{Domestic and international divisions}

In the fluid Portuguese situation, several different visions and goals were however expressed, within the armed forces and among the parties. Simplifying, we can identify three general positions: 1) the pro-European and moderately pro-Western one of Soares, the Socialists but also, in different ways, of other political forces (such as the right of center Popular Democratic Party, Partido Popular Democrático, PPD, later renamed Partido Social Democrata, PSD) and of some leading members of the MFA, who will play a crucial role in the Summer of 1975; 2) the orthodox pro-Soviet approach of the Communist party and of some of its supporters in the armed forces; 3) the populist third-worldism and in some instances Guevarism of part of the military, which found in brigadier Otelo Saraiva de Carvalho, chief of Portuguese Military Security for most of the transition period, its most renowned figure.

A fourth actor or, better, a 'shadow' must nevertheless be considered when discussing the interaction between domestic and international factors during the Portuguese transition to democracy: the possibility of a neo-authoritarian reaction, similar to the one that had led to the downfall of Salvador Allende in Chile. The symbolic power, and therefore the political influence, of this 'Chilean shadow' cannot be underestimated. It shaped the perception of events of all the major actors involved - Portuguese, Western European and American - and conditioned their choices, actions and words. For many Europeans preventing a 'Chileanization' of Portugal became the paramount priority, which justified greater activism and

20. GFL, NSA, Presidential Country Files for Europe and Canada, 1974-1977, Box 10, Kissinger to Ford, 30.09.1974 and Hyland to Kissinger, 30.09.1974. T. SZULC, Lisbon and Washington: behind the Portuguese Revolution, in: Foreign Policy, 3-62(Winter 1975-76); NAUK, FCO, 'FCO 9/2059', Trench to Morgan, 09.10.1974 and Ure to Thomas, 23.10.1974.

21. R. VICKER, Comrade Cunhal. Communist Leader in Portugal's Cabinet Preaches Moderation, in: The Wall Street Journal, 20.02.1975. 
involvement. For most democratic Portuguese forces, the Chile precedent was an ominous reminder of the limits that structural factors and Cold War dynamics posed to the sovereignty of the country. For those looking back nostalgically to Salazar and Caetano it was the last and only hope to reverse the course of history. For Kissinger it was a threat that could be brandished against any further radicalization of the crisis: "they've learned from Chile that if they move too slowly we will do something", the US secretary of State argued in October 1974 while planning a joint covert operation in Portugal with Spanish Foreign minister Pedro Cortina Mauri. ${ }^{22}$

In the eyes of the Europeans, the Chilean shadow provided an additional justification for escalating their efforts in Portugal and preventing a further radicalization of the Portuguese political scene. As Swedish Prime minister Palme would argue during a meeting with Kissinger, Lisbon could "be a Prague" (the reference was to the 1948 Communist coup in Czechoslovakia), but "it will be a short Prague, because the Russians won't be prepared to pay them the economic price. The question then arises whether it will be a jump from a Prague to a Chile $[\ldots]$ the road from Prague to Santiago", Palme said, could indeed be a "short one". 23

For most of 1975 this radicalization did indeed take place. Kissinger's decision to replace US ambassador to Lisbon, Stuart Nash Scott, with former undersecretary of Health, Education and Welfare, Frank Carlucci aroused suspicions in Portugal and elsewhere. Scott had been harshly criticized by Kissinger for his alleged passivity and the moderately liberal estimates produced by the embassy, which suggested prudence and cautioned against open meddling in Portuguese politics. At the time Carlucci was regarded as a staunch anti-Communist, willing to intrude more aggressively in Portuguese political life. Trench, for instance, expressed his "apprehensions about the results of a new go-go American ambassador, who might be over-anxious to demonstrate activity and to rationalize what" was "still a largely irrational scene". Carlucci was soon accused by the radical Portuguese press of being a CIA operative, intent on promoting covert operations aimed at reversing the course undertaken with the revolution. ${ }^{24}$

Fears deriving from outside pressures were compounded by greater political tensions within Portugal and among Portuguese political forces. The fragile postrevolutionary political equilibrium began to vanish. Competition between Socialists and Communists became more intense and bitter. In early 1975, the PCP and the PS clashed over the new labour legislation, with the latter trying to resist a

22. NARA, RG 59, RHK, Box 5, Memorandum of Conversation Kenry Kissinger-Pedro Cortina Mauri, 09.10.1974.

23. NARA, RG 59, RHK, Box 11, Meeting Palme-Kissinger, 30.06.1975.

24. NAUK, FCO 9/2068, Trench to Morgan, 12.11.1974; Callaghan to UK embassy in Washington, 13.11.1974; Foreign Affairs Oral History Collection of the Association for Diplomatic Studies and Training, Library of Congress, Washington, DC (hereinafter FAOC-LOC), Interview with Frank Carlucci, 30.12.1996; Clift to Scowcroft, 28.02.1975; GFL, NSA, Presidential Country Files for Europe and Canada, 1974-1977, Box 10, Scowcroft to Carlucci, undated (ca. February/ March 1975). 
new bill that would facilitate the formation of a single union controlled by the communists. The most radical wing of the military appeared to have the upper hand within the MFA. Tensions between the military and the parties exacerbated the situation. Both seemed to be divided along a classic line: "those in favour of a broad-based participatory democracy and democratic route to socialism on the one hand, and those who espoused the role of a revolutionary vanguard on the other". ${ }^{25}$

Rumors of possible coups, from the Right and the Left, spread uncontrolled. The US Department of State and the Lisbon embassy received various intelligence reports of plots organized by right wing groups. And a coup, theatrical as much as ineffective, did indeed take place. On March 11 Spínola and his supporters staged a military uprising. The attempt failed, but provided the justification for a further shift to the Left. The MFA assumed firm control of the situation. The power of the military was institutionalized through a series of measures that created a sort of military parallel government (The Council of Revolution, Conselho da Revolução), soon to become "the supreme authority in the country", and a 240-men assembly, where executive and legislative prerogatives were confusedly mixed. A Fourth provisional government was formed; while de facto deprived of many of its powers, it had a markedly leftist character. More ominously for the West, for the first time since the revolution Mario Soares lost his post as Foreign minister, although he was replaced by Melo Antunes, a moderate figure who will play a crucial role in the months to come. The political consequences were immediate. Radical economic recipes were tested and implemented. Banks and insurance companies were nationalized. As a consequence, most communications media controlled by the banks or indebted with them - fell under state control. A very progressive land reform was discussed. Accused of collusion with Spínola, several members of old oligarchies were arrested and imprisoned. Political parties were forced to accept an agreement with the MFA, which recognized military supremacy for the next three years, placing the government and the future national assembly in a subordinate position vis-à-vis the Council of Revolution and the MFA assembly. Anti-US propaganda spread unchecked. Carlucci and Kissinger were accused of being behind what the daily "Diário de Notícias" defined a "childish and badly planned coup". ${ }^{26}$

The US and Western Europe observed with perplexity if not outright indignation the course of events in Portugal. American liberal newspapers, which had supported Portugal's revolution and criticized Kissinger's rigidity, denounced the curtailment of political freedoms in Portugal. According to the "Washington

25. K. MAXWELL, The Making ..., op.cit., p.109.

26. Golpe Infantil e Muito Mal Preparado, in: Diário de Notícias, 12.03.1974; Incerteza nas relaçoes luso-americanas apos o malogro da intentona reaccionaria, in: ibid., 14.03.1974; O governo provisorio deixara ha muito de corresponder ao avanço do processo revolutionario, in: ibid., 17.03.1974; Coincidencias com o golpe chileno, in Diário de Lisboa, 11.03.1974; U.S. Says Lisbon Retracts Charge of CIA Coup Role, in: The Washington Post, 15.03.1974; M. ACOCA, U.S. Ambassador to Portugal Protests Article Citing CIA Ties, in: The Washington Post, 29.03.1975; K. MAXWELL, The Making ..., op.cit., pp.110-113. 
Post" "the darkest fears of those who wondered how Portugal could safely navigate from dictatorship to democracy" appeared "to be coming true". "Together with renewed Communist action in Cambodia and Vietnam, and stepped-up Soviet arms shipments and other pressures in the Middle East", "The New York Times" argued "a Communist take-over in Portugal could not fail to bring into serious question what remains of a shaky détente". ${ }^{27}$

Similar concerns were expressed in Europe. NATO's secretary general, Joseph Luns, called a private meeting of the representatives of Belgium, France, Italy, West Germany, the United Kingdom and the United States. The German representative cited "reliable sources [...] which suggested that Portugal was about to be taken over as Czechoslovakia had been after the war". There was a general agreement on the opportunity to promote bilateral approaches to the Soviet Union and to warn it "of the effect on détente of a [communist] takeover" in Portugal. Germany's chancellor Helmut Schmidt made a demarche to the Soviet Union and vainly urged the EEC Nine to "act together" and promote a common demarche to Moscow. Single demarches were undertaken by the UK, the US, Italy, Belgium, Denmark and the Netherlands. Even Western European Communist parties were baffled by PCP's actions. The secretary of the Italian Communist Party (Partito Comunista Italiano, PCI), Enrico Berlinguer, who was pursuing a strategy of dialogue and compromise with the centrist Christian Democratic party (Democrazia Cristiana, DC), expressed "perplexities and reservations" on the course of events in Portugal: "we ourselves", he claimed,

"consider it necessary to assure the full exercise of political faculties to all forces of the left, center and right $[\ldots]$. there is something in recent Portuguese events that does not persuade us".

Cunhal presented such remarks as a form of interference in Portugal's domestic affairs that could "only profit the forces of reaction". According to Trench, the Italian and the Spanish Communist parties seemed "to be by no means pleased by the turn which events have taken in Portugal" and it was even "believed that the Soviet Union" had "advised a less impetuous advance, for fear of spoiling their game in a wider field". 28

These preoccupations were somehow tempered by the necessity to avoid explicit pressures on Portugal, which could backfire and accelerate the shift to the Left everyone intended to prevent. The French president Valéry Giscard d'Estaing, who had opposed the common EEC demarche solicited by Bonn, maintained

27. Portugal Lurches Left, in The Washington Post, 18.03.1975; Lisbon's Real Coup, in: The New York Times, 15.03.1975.

28. NAUK, FCO, 'FCO 9/2269', Logan to FCO, 22.03.1975 and Henderson to FCO, 27.03.1975; NAUK, FCO, 'FCO 9/2270', Trench to FCO, 09.04.1975; J. RANDAL, European Liberals Uneasy About Direction Portugal Taking, in: Washington Post, 26.03.1975; C. STERLING, Italian Communists: a Portuguese Connection, in: Washington Post, 28.03.1975; A. RUBBI, Il mondo di Berlinguer, Napoleone, Roma, 1994, pp.73-75 and S. PONS, Berlinguer e la fine del comunismo, Einaudi, Torino, 2006, pp.60-66. 
that "the nature of the Portuguese regime was a Portuguese affair" and that he was "against diplomatic intervention with the Portuguese government". Such intervention would have been justified only if "the actions of the Portuguese regime" had "upset or threatened to upset the international strategic balance, for instance by granting bases to the Russians". Quite surprisingly, Frank Carlucci concurred. The US ambassador believed that a strategy of "rebuilding the moderates" was the wisest one and that it was necessary to wait for the forthcoming national elections before considering Portugal lost for good. ${ }^{29}$

The common concern for the fate of Portugal did not stimulate a renewed Transatlantic cohesion, and even catalyzed a rift within the US State Department, with the embassy in Lisbon adopting a posture that secretary of State Henry Kissinger found wrong and naïve. Kissinger scorned Carlucci for his overoptimistic reports and unwise suggestions, which were reminiscent of those of former and much criticized ambassador Scott. Moreover, Kissinger continued not to trust Soares, the Socialists and the other non-Communist democratic forces, and did not believe they could offer an alternative. In light of the situation, the secretary of State claimed, it was better an extreme outcome of the crisis: a solidly pro-NATO, even if undemocratic, regime or a pro-Soviet Portugal, which would at least "vaccinate" Europe from leftist, neutralist and third-force viruses. Kissinger explained this theory, soon to become famous as the "inoculation theory", in a backchannel reply to chancellor Schmidt: "a Communist takeover in Portugal would be a disastrous blow to the Alliance and would play into the hands of various political forces in Europe on both the left and the right. At the same time", Kissinger maintained, "such blatant development would at least confront us with a straightforward issue, around which I would expect the Alliance to rally". ${ }^{30}$

These two different views determined a very different reaction to the national elections for the Constitutional Assembly, which took place regularly on April 25, 1975, the first anniversary of the revolution. Despite dire warnings, the Communists and their allies fared poorly at the polls, receiving little more than $16 \%$ of the votes. The turnout was extraordinary (almost $92 \%$ ) and showed how democracy had rapidly taken hold in Portugal. The clear winners of the election were the most pro-European parties. The Socialist Party of Mario Soares took approximately $38 \%$ of the votes. Sá Carneiro's Popular Democrats received instead $26.5 \%$. The strength of the PS was emphasized by its success in the more developed and urban areas in the country (in Lisbon the Socialists won more than $46 \%$ of the votes). The elections aroused enthusiasm in Europe and the United States. "Portugal for Freedom", titled the editorial of "The New York Times". ambassador Trench presented the elections as a "signal opportunity" for the British government, "and the West in general, to underpin the Portuguese forces working

29. NAUK, FCO, 'FCO 9/2269', Tomkins to FCO, 26.03.1975; Carlucci to secretary of State, 22 March 1975; GFL, NSA, Presidential Country Files for Europe and Canada, 1974-1977, Box 11, FAOC-LOC, Interview with Frank Carlucci; Kissinger to Carlucci, 03.04.1975.

30. NARA, RG 59, RHK, Box 2, Kissinger to Schmidt, 12.04.1975. 
for representative democracy both by appropriate expressions of support as well as tangible gestures of assistance". ${ }^{31}$

Again, Kissinger disagreed offering an interpretation which the British Foreign Office dismissed as "apocalyptic". According to the US secretary of State, the elections had been a "popularity contest with no significance [...] a public opinion poll $[\ldots]$ not translatable into political action". The real problem was "the impact on NATO of a revolutionary government, in which the Communists" were "in the key role of pursuing essentially neutralist policies [...]. And that" had not "in any remote way been affected" by the elections. "A Soviet-allied dictatorship", the US secretary of State claimed, was a "better outcome for the United States". 32

Again, Kissinger's position and his inflexible hostility to Soares and the Socialists became public. From the pages of the "New York Times", one of the most astute commentators of Portuguese politics, Princeton scholar Kenneth Maxwell, reminded readers that Kissinger had been "hostile to the democratic revolution in Portugal from the beginning", and considered all "socialists and neutralists" as "crypto-communists". "The great majority of the Portuguese people and Army think of themselves as socialists and neutralists", Maxwell correctly pointed out. It was therefore

"worth remembering before the search begins for some 'moderate' to 'turn the tide' that in such circumstances 'moderates' often turn out to be a general Augusto Pinochet. [...] And that is an old path trodden too often. Indeed, trodden so often that if it is America that the Portuguese now fear, as they do, there lies the reason". 33

The weeks following the elections were characterized by four clashes.

The first one was within the Portuguese Left, with the Socialists trying to exploit the results of the election and reaffirm their primacy in Portuguese politics, and the Communist dismissing the importance of the vote and seeking to consolidate the power they had gained in the previous months. Intoxicated with such power, orthodoxically Leninist in their view of politics, and dismissive of the broader repercussions of the Portuguese situation on Western European communism and the left in general, Cunhal and his followers believed that the situation could be exploited to give a further, and definitive, push to the revolutionary process. In a famous interview with Italian journalist Oriana Fallaci, Cunhal claimed that the PCP had "no use for a popular front with the socialists, a pact like the one formulated" in Italy "by Nenni and Togliatti in 1948". "The revolution doesn't respect old laws; it makes new ones", Cunhal affirmed. Democracy meant "getting rid of capitalism, of trusts [...] not what you pluralists

31. Portugal for Freedom, The New York Times, 27.04.1975; NAUK, FCO, 'FCO 9/2270', Trench to FCO, 06.05.1975.

32. GFL, NSA, MC, Box 11, Memorandum of conversation Ford/Kissinger/Scowcroft, 01.05.1975; NARA, R5 59, Lot File 78D443, Box 7, Meeting of secretary of State's staff, 25 and 28.04, 01.05.1974; NAUK, FCO 9/2291, Ramsbotham to Foreign Office, 09.05.1975; DBPO, series III, vol.V, 439, Trench to Foreign Office, 06.05.1975.

33. K. MAXWELL, Portugal's Uphill Path, in: The New York Times, 12.05.1975. 
mean $[\ldots]$. In Portugal, henceforth, there" existed "no possibility for a democracy such as the" Western European "kind". "Your Western democracy", Cunhal said

"is not enough for us [...]. We don't even want socialism, or, rather, a dream of socialism, like yours [...]. Portugal will never be a country of democratic freedoms and monopolies. It won't be a fellow traveller of your bourgeois democracies. [...] We shall certainly not have a social democratic Portugal".

Cunhal had spent so many years in prison and in Moscow, Italian communist Gianfranco Pajetta sarcastically observed, that "he was completely out of the mainstream of modern European political thinking". ${ }^{34}$

The second clash was within the Armed Forces Movement, where moderate leftists such as Melo Antunes, pro-Communist as Gonçalves, radical (and naïve) third-worldist as Carvalho, and moderate and centrist figures as Ramalho Eanes cohabited more and more uneasily. The shift to the Left, which continued unabated throughout the Spring and 'Hot Summer' of 1975, induced the moderates to countermobilize and form a heterogeneous anti-Communist coalition. Antunes and his allies created a group, the so-called "group of Nine", which soon became one of the favourite interlocutors of the West, progressively replacing in this role Soares and the PS.

The third clash was that between the US and its main European partners. To the latter, the electoral results and the fluid situation within the MFA proved that the evolution towards a democratic and pro-Atlantic Portugal was feasible and likely. Kissinger, instead, was more pessimistic and seemed to reject even an option - that of a Socialist Portugal that continued to be a member of NATO - which Western Europeans considered possible and indeed desirable. "We feel" - Kissinger said -

"that helping radicals does not help moderates. Portugal could develop into a combination of Yugoslavia and Algeria. If it were to stay in NATO in that form it could have a bad impact on Italy, leading to historical compromise which we do not want".

The "inoculation theory" was not abandoned, the possibility to replace Portugal with Spain in NATO was discussed and the secretary of State even flirted with the idea of supporting the staunchly conservative separatist movement of the Azores, which his right arm, Helmut Sonnenfeldt, urged to take "seriously" since in case of necessity the islands could be transformed into a "sort of Atlantic Taiwan". ${ }^{35}$

34. O. FALLACI, I Care Nothing for Elections, ha, ha!, interview with Alvaro Cunhal, in: New York Times Magazine, 13.07.1975. Cunhal made similar considerations during a meeting of the Council of Revolution (Conselho da Revolução). See Mario Soares Papers (hereinafter MSP), Fundação Mario Soares, Lisbon (hereinafter FMS), Após 25 de abril 1974,_Pasta 02975.013, Meeting Conselho da Revolução, 23.05.1975. Pajetta quoted in T. SZULC, op.cit., p.48. On the tense meeting between Pajetta and Cunhal, which took place the $15^{\text {th }}$ of July 1975 , see the reconstruction by A. RUBBI, op.cit., pp.73-76.

35. GFL, NSA, MC, Box 12, Memorandum of Conversation Kissinger/Ford/Pope Paul VI, 03.06.1975; Temporary Parallel File (hereinafter HK\&BS, TPF), Box A1, Henry Kissinger and Brent Scowcroft: Files, (1972) 1974-1977, Ingersoll to Scowcroft, 05.06.1975; DBPO, Series III, Volume V, 450, Killick to Goodison, 09.06.1975. 
The fourth and last clash was the one between Carlucci and Kissinger. Despite his fame, the American ambassador worked more and more closely with Soares, Antunes and the Western European representatives in Lisbon. Carlucci dismissed out of hand the opportunity to support the Azorean "separatists" ("ultra-right splinter groups", he claimed, could "only harm" US interests), and endorsed what we could define as the 'Euro-socialist' way out of the crisis, recognizing the lack of alternatives and the strong risk of a neo-authoritarian regression which Kissinger seemed instead to prefer. ${ }^{36}$

These clashes took place in the midst of an economic situation in Portugal which was becoming every day more critical. Foreign capitals were leaving the country at accelerated speed; inflation was rampant; once abundant gold reserves diminished drastically; paralyzed by strikes and political conflict, industrial activity and productivity dropped significantly; alternative sources of income, as remittances from emigrants, virtually disappeared. On top of it, the surge of returnees from Africa placed an additional burden on what was already a very strained economy. ${ }^{37}$

\section{A European solution}

During the Summer of 1975 political conflicts within Portugal intensified and sometimes turned violent; in the conservative regions of the North several offices of the PCP were attacked and burned. The Socialists and the Popular Democrats decided to exit the government that had been formed after the March 11 coup. In early August Gonçalves formed a fifth provisional government, without the PS and the PPD. In a famous interview to the French magazine "Nouvel Observateur" Antunes criticized the Prime minister, the PCP and their allies in the MFA who were trying to impose "bureaucratic collectivism" on the unwilling Portuguese population: "this process", Antunes claimed "is leading us straight into a totalitarianism [...] moreover the Communist strategy is also failing in Portugal: it is only clearing the way for a fascist reaction". 38

36. B. GOMES, T. MOREIRA de SÁ, Carlucci vs. Kissinger. Os EUA e a Revolução Portuguesa, Dom Quixote, Lisbon, 2008. GFL, NSA, Presidential Country Files for Europe and Canada, 1974-1977, Box 1 and 20, Carlucci to Kissinger, 21.04.1975; Colby to Kissinger, 31.05.1975; Heckler to Ford, 25.07.1975.

37. A.M. WILliAMS, Tourism in Portugal: From Polarization to New Forms of Economic Integration? and D. CORKILL, Portugal's Changing Integration into the European and Global Economy, in: S. SYRETT (ed.), Contemporary Portugal, op.cit., pp.25-45 and 83-103; P. LAINS, The Portuguese Economy in the Twentieth Century; Growth and Structural Change, in: A.C. PINTO (ed.), Contemporary Portugal. Politics, Society and Culture, Columbia University Press, New York, 2003, pp.119-138.

38. NAUK, FCO 9/2272, Trench to Foreign Office, 11.08.1975; M. ANTUNES, op.cit., pp.152-157 and 234-243. 
It was exactly what European socialist and social-democrats had most feared since the fall of the regime: a radicalization of the revolutionary process that would justify and legitimate an authoritarian (i.e: "Chilean") response. Answering Antunes's calls for "strong interventions from the Western Europeans" and the United States, various NATO countries made demarches to president Costa Gomes. Carlucci deemed Antunes as the best hope for reversing the course of events. The European Council held an emergency debate where closer economic and financial cooperation between the EEC and Portugal were explicitly linked to the development of a "pluralist democracy" in Portugal. West European socialists established a "Committee of Friendship and Solidarity with Democracy and Socialism in Portugal", and denounced vigorously Soviet interference in Portuguese affairs (which Kissinger instead minimized). British Prime minister Harold Wilson accused Moscow of pouring \$ 100 million a year into the PCP. Speaking with Mario Soares, Willy Brandt, who chaired the committee, made clear that "as soon as Portugal got a democratic government, all the countries represented in the Group would be ready to start serious discussions about economic cooperation". ${ }^{39}$

Again, European criticism of Portugal's drift to the Left combined with renewed concerns over the possibility that this could cause a rightist reaction. Rightwing groups operated with Spanish backing in the North. From Paris, Spínola was trying to establish contacts with the anti-Communist forces. During the hot Summer, and in late August in particular, Portugal appeared to be on the verge of a civil war. Under heavy domestic and international pressure, the fifth provisional government had a very short life. After tense discussions, a sixth provisional government was installed in mid September. It was chaired by admiral Pinheiro de Azevedo; Melo Antunes was Foreign minister; the PS and the moderate wing of the MFA dominated the new executive. "The new government and revolutionary Council", Trench maintained,

"probably have a better assembly of talent, and a composition more representative of the various constructive power groups in the country, than any previous authorities constituted since the revolution. They stand a reasonable chance of putting Portugal back on a sound constitutional and economic course and once they have demonstrated their capacities it may be appropriate, for us and our allies in Europe and the US, to give them material evidence of our encouragement".

Material evidence was indeed forthcoming. The Ford administration amended the budget proposal to fiscal year 1976 to include extraordinary assistance to Portugal. US aid was finally matched by a conspicuous EEC program of economic assistance

39. The countries represented in the Committee were France, Sweden, West Germany, the United Kingdom and the Netherlands. NAUK, FCO 9/2285, Callaghan to Trench, 22.07.1975; NAUK, FCO 9/2286, Working Paper Committee on Portugal, 27.08.1975; NAUK, FCO 9/2272, Ramsbotham to Foreign Office, 28.08.1975; Carlucci to Kissinger, 22.08 and 27.08.1975; GFL, NSA, Presidential Country Files for Europe and Canada, 1974-1977, Box 11; DBPO, series III, vol.V, 482-483, Callaghan to Trench, 26.08.1975; Bernard D. Nossiter, Socialists Plan Portugal Aid, 06.09.1975. 
for Portugal. The program included a 175 million loan from the European Investment Bank and a declaration of support for Portuguese requests to the IMF for balance of payments assistance. It was just the beginning of a trend that would accelerate in the following years. The revolution came to a final end in late November, when radical paratroopers staged a last leftist uprising, whose failure was "the definitive coup de grâce to the dreams of Socialist revolution so avidly espoused a few months before by Alvaro Cunhal and his allies". ${ }^{40}$

Political mistakes by the PCP and its allies in the MFA help to explain why these dreams did not come true. Furthermore, the Portuguese people spoke out strongly against such dreams, as shown by the results (and the turnout) of the April 1975 elections. Despite Cunhal's dismissive remarks on its effective importance, the vote demonstrated that a large majority of Portuguese preferred a pluralist (and very West European) democratic model. Finally, structural factors, geopolitical as well as economic, played a crucial role, progressively curtailing the options available during the transitional period. Cold War partitions as well as economic interdependence limited Portugal's sovereignty, as all the Portuguese actors soon discovered.

At the end it was simply unrealistic for Portugal to opt for a Socialist outcome of the transition, in whatever variant (Soviet/Eastern European; Peruvian/ThirdWorldist) this solution was declined. Antunes and other members of the MFA rapidly understood it. But they were also aware of the risks Portugal was facing. An authoritarian response was indeed possible. Cold War logics and geopolitical considerations could justify it, as Kissinger made abundantly clear. The "Chilean shadow" (or, for that matter, the Greek precedent) were there to remind everyone that the definitive end of authoritarian rule in Portugal could not be taken for granted. Indeed, the recent history of Portugal itself offered a powerful reminder: in spite of everything, pre-1974 Portugal had been a reliable member of the Atlantic alliance and had developed deeper economic ties with democratic Western Europe, whether through participation to EFTA or cooperation with the EEC. At the end, however, Europe and European democratic socialism offered a crucial safety net, which helped Portugal to prevent a return to the pre-1974 status. The early/ mid 1970s were in many ways the heyday of Western European democratic socialism. Popular as it was, the hope that this form of socialism could offer a model of modernization and development for the least developed European countries, such as Portugal, and the Third World soon proved to be illusory. The importance played by 'Euro-socialist' forces in helping and facilitating the transition to democracy in Portugal cannot however be denied or underestimated.

40. K. MAXWELL, The Making ..., op.cit., p.157.; NAUK, FCO, 'FCO 9/2272', Trench to FCO, 20.09.1975; Memorandum of conversation Callaghan/Sauvagnargues/Genscher/Kissinger, 24 September 1975; NAUK, FCO 9//2272, Trench to Callaghan, 17, 18 and 20.09.1975; NAUK, FCO 9//2272, Briefing Memorandum Meeting Kissinger/Ford/Antunes, 10.10.1975. 